\title{
AUSTRALIAN LABOUR AND THE PROFINTERN
}

In common with many other countries, Australia has had, since 1920, a Communist Party, which is an obvious and continuing symbol of international reaction to the Russian Revolution of 1917. Naturally enough the formation of this Communist Party and its subsequent history has attracted a degree of attention from historians and scholars of Communist movements and Australian politics. ${ }^{1}$ The impact of the Profintern, on the other hand, has been completely neglected. ${ }^{2}$ Even at the international level no full-scale study of the Profintern and its related trade-union organisations is yet available, and though one scholar has noticed that in Australia "the history of communism in the unions is [.. .] separate from CPA political history", ${ }^{3}$ the bases of this separation have been left relatively unexplored. This article seeks to examine Moscow's links with the Australian tradeunion movement via the Profintern in the period 1920-35. It would seem that these links overshadowed the CPA as a "Communist" influence in the Australian context, at least for the first decade of the Comintern's existence. The separation of CPA history from the wider influence of Communism in the unions is discernible almost from the very start.

1 For studies of the CPA see A. Davidson, The Communist Party of Australia: A Short History (Stanford, 1969) (hereafter The CPA); World Communism: A Handbook 1918-1965, ed. by W. S. Sworakowski (Stanford, 1973), pp. 18-21; R. Gollan, Revolutionaries and Reformists: Communism and the Australian Labour Movement 1920-1955 (Canberra, 1975).

2 The name Profintern derives from the Russian abbreviation for trade-union International. Australian unionists referred to the organisation as the Red International of Labor Unions (RILU) or, more often, simply the Red International. I have used the various names interchangeably throughout this text. On the formation and general history of the Profintern see L. L. Lorwin, Labor and Internationalism (New York, 1929), esp. pp. 228-46, 530-37; W. Z. Foster, History of the Three Internationals (New York, 1955), pp. 272-307; World Communism, op. cit., pp. 375-77.

3 Davidson, The CPA, p. 183. 


\section{LABOUR AND THE RUSSIAN REVOLUTION}

Labour internationalism in Australia was very largely a result of the impact of World War I. Organised labour had before 1914 achieved some remarkable and outstanding successes. In the early 1890's the trade-union movement had given birth to the Labor Party, which had thenceforth developed as a party to which trade unions belonged, but which also attained to wider electoral support and parliamentary organisation. Success attended labour's entry into politics from the start, and by 1915 the Labor Party had tasted office in the Commonwealth Parliament and in every Australian State. ${ }^{4}$ Along with this development, however, came an increasing tendency on the part of the ALP to oppose trade-union programmes and policies, the more so if these challenged Labor's electoral popularity or governmental responsibilities. In 1916 the Labor Party split over the issue of conscription for overseas military service and the leading politicians of pre-war years were expelled from the ALP. It was almost a decade before the politicians who advocated reform and parliamentary Socialism regained an approximation of their former status. In the interim period the labour movement was wracked by ideological disputes of a degree and intensity never previously encountered.

The main challenge to Labor reformism came from a variety of leftwing minority parties, whose influence grew dramatically towards the end of World War I. Advocates of such extremist ideologies were strongly opposed by the many moderate politicians who had remained in the Labor Party and by right-wing unions like the Australian Workers' Union. Nevertheless in the years immediately following World War I it was the radical Left who made the running; the strange and complicated world of the left-wing ideologues suddenly attained a quantum of significance.

By 1919 the situation on the far Left of the labour movement was very confused. There were at this stage around a dozen different parties and groups, apart from the ALP, competing for the allegiance of members of the labour movement. ${ }^{5}$ The dominant influence was American Syndicalism, more specifically a spectrum of ideas associated with the Industrial Workers of the World in both its "Chicago" and De Leonist or "Detroit"

4 On the rise of the Labor Party and the history of the labour movement up to World War I see R. Gollan, Radical and Working Class Politics (Melbourne, 1960); B. Nairn, Civilising Capitalism (Canberra, 1973); Labor in Politics, ed. by D. J. Murphy (Brisbane, 1975).

5 See I. Turner, Industrial Labour and Politics (Canberra, 1965), esp. pp. 232-33. 
variations. ${ }^{6}$ At the same time a lively interest was maintained in European Socialism and developments in the British labour movement. A deep line of division ran through all the left-wing parties over the correct policy to adopt vis-à-vis the existing labour movement. Many members of the extreme Left, influenced by IWW theory and by purist Marxian ideologies, favoured "dual unionism" and uncompromising hostility to the ALP. This habit of thinking later spilled over into the CPA, a party which captured the allegiance of almost all the ideologues of the extreme Left when it was formed in $1920 .{ }^{7}$ Far more important than the sectarian Left, however, were those parties and groups mixing their doctrinal beliefs with a very Australian pragmatism and lack of concern for theoretical consistency, which allowed notions of "One Big Unionism" and Socialist reconstruction to be applied to the mainstream labour movement. In several States parties such as the Victorian Socialist Party and the Sydney-based Social Democratic League were particularly dedicated to channelling left-wing ideology into the affairs of the ALP. ${ }^{8}$ Such parties exerted their greatest influence first on the trade unions, and indirectly through these unions on the ALP. With the exception of the right-wing Australian Workers' Union most of the powerful unions had many activists and leaders strongly influenced by Socialist doctrines. One such leader was A. C. Willis, secretary of the powerful Miners' Federation, whose eclectic combination of Guild Socialist and Syndicalist ideas helped to inspire his union to completely reconstitute itself as the "mining section" of a proposed One Big U nion, which would embrace all trade unions in its structure. ${ }^{9}$ In 1919 Willis led a breakaway movement out of the ALP to form a new Industrial Socialist Labor Party. Throughout the next decade he played a leading role in both trade-union and ALP affairs, re-entering the Labor Party in 1923 as New South Wales State President! Two years later he assumed leadership of the State Labor Party's parliamentary caucus in the Legislative Council and was also president of the executive council and a leading Minister in the Government of Premier J. T. Lang. ${ }^{10}$

On the left of Willis was J. S. Garden, secretary of the New South Wales Labor Council (the central co-ordinating body for the trade-union movement in that State). Garden graduated from membership of the Industrial

6 Ibid., pp. 55-67, 182ff.

7 Gollan, Revolutionaries and Reformists, op. cit., pp. 2ff.

8 Turner, Industrial Labour and Politics, op. cit., pp. 56-57, 191, note.

9 Ibid., p. 194.

${ }^{10}$ For a participant's view of these developments see J. T. Lang, I Remember (Sydney, 1956), esp. pp. 197-202, 310-31. For a recent study see Jack Lang, ed. by H. Radi and P. Spearritt (Sydney, 1977), pp. 35-36, 50-60. 
Socialist Labor Party in 1919 to a founding role in the setting up of the CPA in $1920 .{ }^{11}$ In the mid 1920's, however, he followed Willis back into close support of the New South Wales ALP and shortly afterwards was expelled from the CPA. He later became a Labor parliamentarian. Garden's own progression through left-wing Socialism and Communism back into membership of the ALP was also paralleled by a wide spectrum of Sydney's trade-union leaders, known collectively as the Trades Hall Reds. Leaders like Willis, Garden and the Trades Hall Reds constituted a very powerful left-wing influence on the mainstream labour movement throughout the 1920's.

Outside New South Wales developments were much less spectacular, but generally somewhat similar. In many ways the different developments in various States were a measure of the relative weight of conservative influences, which were weakest in industrialised centres such as New South Wales, and strongest in outlying States such as Queensland and Western Australia. Yet in all States there were echoes of the situation in New South Wales. Through the close association between trade-union leaders and Socialism, left-wing ideas flowed into the affairs of the wider labour movement. As time passed these ideas were modified and diluted, partly through the revival of the Labor Party's electoral fortunes (which greatly strengthened the hand of the mostly moderate and reformist parliamentary wing of the labour movement), partly through the very success of left-wing unionists in attaining positions of power (which brought with it the necessity to balance gains made against ideological purity). In the years immediately following World War I, however, the moderation and reformism previously characteristic of Australian labour was under serious challenge.

The result was a movement towards radical reorganisation of labour institutions. In these years hopes of creating a unified One Big Union dominated the thinking of many leading unionists. ${ }^{12}$ An idea originally deriving from IWW theory, the movement for One Big Union was promoted in several forms by various left-wing groups. ${ }^{13}$ At an AllAustralian Trade Union Congress held in Melbourne in 1921 a One Big

11 Garden's career is sketched in B. Lazitch and M. M. Drachkovitch, Biographical Dictionary of the Comintern (Stanford, 1973). For more polemical and hostile accounts see M. H. Ellis, The Red Road (Sydney, 1932); id., The Garden Path (Sydney, 1949).

12 For detailed studies of the one-big-union movement see Turner, Industrial Labour and Politics, esp. pp. 182-222; V. G. Childe, How Labour Governs (London, 1923), esp. pp. 151-81; R. Gollan, The Coalminers of New South Wales (Melbourne, 1963), pp. $157-76$.

${ }^{13}$ Cited in Turner, Industrial Labour and Politics, p. 184. 
Union plan was adopted for a new Australasian Workers' Union (a title aimed at ensuring the co-operation of the Australian Workers' Union, which was now temporarily converted to One Big Union ideals). This Congress, which claimed to represent every trade union in Australia, had been called by the Labor Party Federal Executive in an attempt to find a basis for unity with the radical unionists. The unions, however, insisted that the ALP adopt as its objective "the socialisation of production, distribution and exchange", and began moves towards their own reorganisation along One Big Union lines. ${ }^{14}$

The Left also promoted policies of co-operating with the international Socialist movement, based on a rather inflated and naïve view of developments overseas. The Bolshevik Revolution naturally occasioned much discussion in the Socialist parties involved in the affairs of the trade unions and the labour movement. ${ }^{15}$ Many unionists, and a number of Labor spokesmen, came to view developments in other lands as proof that the capitalist system was bankrupt and about to collapse. ${ }^{16}$ In 1919 Frank Anstey, soon to be elected as deputy leader of the Australian parliamentary Labor Party, published his book Red Europe, wherein he argued that the overthrow of capitalism was certain and inevitable, and that the world revolution was nigh. ${ }^{17}$ It is unlikely that his views were shared by a majority of Labor politicians, especially those still ensconced in State politics, but Anstey's views were frequently echoed in the broader labour movement. ${ }^{18}$ Certainly there was a widespread belief that the hostile attitude of the Allied powers towards the new Russian Government could only lead to intensification and escalation of class struggle. ${ }^{19}$ Australian labour was in fact deeply affected by the "Red Mirage" 20 of the immediate post-war years, and there was considerable interest in the nature of the new order in Russia and the relevance of developments overseas to the Australian situation.

14 Ibid., pp. 218-26; L. F. Crisp, The Australian Federal Labour Party 1901-1951 (London, 1955), pp. 277-82.

${ }^{15}$ See esp. the booklet by R. S. Ross, Revolution in Russia and Australia (Melbourne, 1920). For an academic study see P. J. O'Farrell, "The Russian Revolution and the Labour Movements of Australia and New Zealand, 1917-1922”, in: International Review of Social History, VIII (1963), pp. 177-97.

${ }_{16}$ See J. Robertson, J. H. Scullin (Perth, 1974), pp. 66-67; Crisp, The Australian Federal Labour Party, op. cit., p. 282.

${ }^{17}$ F. Anstey, Red Europe (Melbourne, 1919). Anstey was deputy-leader of the ALP from 1922 to 1927.

18 Ibid., p. 186; Worker (Brisbane), January 1920; Labor Call (Melbourne), 11 March. 19 Australian Worker (Sydney), 12, 19 and 26 August 1920; Daily Herald (Adelaide), 23 August.

20 On this see D. Mitchell, 1919: Red Mirage (London, 1970). 


\section{EARLY LINKS WITH THE PREFINTERN}

Of the many revolutionaries who flocked to Russia in the wake of the Bolshevik uprising two men were soon accepted by Comintern leaders as having knowledge of the affairs of the Australian labour movement. One of these men was F. A. Sergeev, better known in Russia as Artem, a dedicated follower of Lenin who had lived in Australia from 1911 to 1917. While in Australia he had been a member of the doctrinaire Marxist Australian Socialist Party, and was an active trade unionist and influential figure in the small Russian community centred in Brisbane. After returning to Russia in 1917 he quickly became a member of the Central Committee of the Russian Communist Party and a Commissar. He was a delegate to the Second Congress of the Comintern in July 1920, and may also have served on the Executive Committee of the Communist International. ${ }^{21}$

The second man was Paul Freeman, a one-time IWW agitator, whose dramatic and much-publicised deportation from Australia in 1919 had made him a local cause célèbre. ${ }^{22}$ Freeman arrived in Russia via Germany (to where he had been deported) in time to attend the Second Congress of the Comintern and sought representation as a delegate from the Australian IWW. Lacking credentials he was apparently refused such status, though he was subsequently a candidate for the ECCI at the Third Comintern Congress of June-July 1921.23 After the Second Comintern Congress Freeman was also despatched on a secret mission to Australia, where he acted as a representative of the International Council of Revolutionary Trade and Industrial Unions. ${ }^{24}$ This body was charged with the task of establishing a "red" trade-union organisation which would counter the influence of the Amsterdam-based International Federation of Trade Unions. His task was to encourage the attendance of Australian unionists at the forthcoming first congress of the Profintern.

The Profintern was established at a congress of unionists which coincided with the Third Comintern Congress of June-July 1921. At its

21 On Artem's career as a Bolshevik leader see Davidson, The CPA, pp. 21, 40, note; Great Soviet Encyclopedia, II (New York, 1973), p. 373. See also E. H. Carr, The Bolshevik Revolution 1917-1923, I (London, 1950), pp. 204 and 301, notes. Artem does not appear as a member of the ECCI in the study by V. Kahan, "The Communist International, 1919-43: The Personnel of its Highest Bodies", in: International Review of Social History, XXI (1976), pp. 151-85.

22 Davidson, The CPA, pp. 16, 20, note.

23 Kahan, loc. cit., p. 159.

24 On Freeman's visit see B. Walker, Solidarity Forever (Melbourne, 1972), pp. 86-94. 
important Third Congress the Comintern had decided on a change of policy summed up in the slogan "To the Masses!" Apparently the newly emerging "united front" policy had been partly initiated in advance of the Profintern congress for, at least so far as Australian unions were concerned, recruitment seems to have been on a wide basis. ${ }^{25}$ While in Australia, Freeman contacted a range of activist groups and succeeded in attracting significant left-wing union representation to Moscow. The Labor Council of New South Wales sent its president, J. Howie, who was apparently also in possession of credentials from Trades Hall Councils in other States. ${ }^{26}$ Howie had a short-lived association with the Industrial Socialist Labor Party, but following his return from Moscow became well-known as a Communist. The other Australians who were in Moscow at the time of the Profintern's founding congress were two professed Communists: W. P. Earsman (a founding figure in the Guild-Socialist-inspired Labor College movement in Australia and a close associate of J. S. Garden), and A. Rees, a militant unionist from Broken Hill. Despite Howie's previous association with non-Leninist doctrines he seems to have accepted the conduct and decisions of the Profintern congress without serious criticism. ${ }^{27}$

The structure and organisation of the new trade-union International was the subject of long and bitter debate at the Profintern congress. Though the Russians attempted to have both trade-union and political organisations incorporated under a single International, a compromise had to be reached with Syndicalist elements ${ }^{28}$ It was agreed that the new body should be considered as having an "organic" relationship with the Comintern, with representation from each of these Internationals upon the executive committee of the other. ${ }^{29}$ Though this meant that the Profintern was from the start open to control by the Comintern, in practice a certain degree of latitude operated so as to encourage continued affiliation of Syndicalistinfluenced unions with the Red International. Indeed the relationship between the Profintern and Comintern was marked by continuing obfuscation and lack of clarity as to their respective roles. ${ }^{30}$ In the absence of annual congresses after 1922 the policy of the Profintern was largely

25 But cf. the account of the recruitment of British trade-union representatives to the first Profintern congress in R. Martin, Communism and the British Trade Unions 1924-1933 (Oxford, 1969), p. 12. See also D. F. Calhoun, The United Front. The TUC and the Russians 1923-1928 (Cambridge, 1976), pp. 12-20, 30-31.

26 See J. Howie, Reds in Congress. First Congress of the Red International of Labour Unions (Sydney, n.d.), p. 7.

27 Ibid., esp. pp. 34-35. See also Davidson, The CPA, p. 23.

28 See Lorwin, Labor and Internationalism, op. cit., p. 230.

29 Ibid., p. 231; Howie, Reds in Congress, op. cit., p. 36.

30 Foster, History of the Three Internationals, op. cit., p. 278. 
controlled by the Russian-dominated RILU executive under the guidance of its general secretary, the one-time Menshevik A. Lozovsky (S. A. Dridzo). ${ }^{31}$ For the remainder of the 1920's the Profintern seems to have followed a policy which was a vector of pressures exerted by the Comintern, by the Profintern's own national "sections" (its affiliated trade-union organisations), and by the changing balance of power in the Russian Bolshevik Party.

Following the Profintern congress a number of Australian unionists who had been delayed in transit arrived in Moscow. Three of these unionists were represented at a meeting with the International Propaganda Committee of Transport Workers in August 1921. They were W. Smith, a member of the Victorian Socialist Party and an official of the railways' union, and W. Casey and P. Kelly of the seamen's union. ${ }^{32}$ Other union representatives included Tom Barker (a one-time leader of the Australian IWW), ${ }^{33}$ George Williams of the American IWW, O. Riger of the German union of seamen, and A. Lozovsky. The meeting constituted itself as a joint conference of seamen and transport workers, and resolved to establish propaganda bureaux in all the main ports of the world, which would work in liaison with organisations affiliated with the Profintern. However, the meeting was marred by a walk-out of German and Finnish seamen who favoured the setting up of an autonomous organisation for seamen. ${ }^{34}$

As well as discussing industrial matters Australian unionists in Moscow assisted in resolving the factional disputes which had broken out in the newly-formed CPA. Soon after the founding of the Communist Party a split had developed between the union radicals led by Garden, and a more purist Marxist group who had earlier been associated with the Australian Socialist Party. Each group sought Comintern endorsement of their stand. ${ }^{35}$ Paul Freeman openly supported the ASP and so did Artem. However, on 24 July 1921 both these men were killed in a train accident, while two other Socialist Party supporters, P. Lamb and A. Rees were injured and temporarily incapacitated. Thus, when a conference was held to achieve unity in the Communist Party the ASP case went largely by default, and W. P. Earsman was able to return to Australia with a "unity"

31 See Martin, Communism and the British Trade Unions, op. cit., pp. 14-15; Lazitch and Drachkovitch, Biographical Dictionary of the Comintern, op. cit., pp. 239-41.

32 On W. Smith see Davidson, The CPA, p. 18. For a full account of the conference see Casey's "Russian Report" in the Adela Pankhurst and Tom Walsh Collection, Australian National Library, Canberra, Ms. 5894.

33 See Davidson, The CPA, pp. 6, 17, note.

34 Casey's "Russian Report".

${ }^{35}$ See Davidson, The CPA, pp. $22 \mathrm{ff}$. 
decision which meant effective victory for Garden and the Trades Hall Reds. From this time onwards the pattern of both Comintern and Profintern influence in Australia was involved with the history of a group who were "red" trade unionists first and purist Communists second. For some of the unionists who visited Moscow in 1921 (and particularly those who participated in the conference of the International Propaganda Committee of Transport Workers) any further involvement even with the Red International was spasmodic and occasional. For the Trades Hall Reds the involvement was more sustained, but with no close supervision of their affairs through the medium of the Comintern they were to take the CPA along a rather unorthodox path.

In Australia the early labour enthusiasm for the Russian Revolution was already beginning to wane. Following the May Day celebrations of 1921 Sydney for a brief period witnessed ex-soldier riots against Bolshevism not unlike those described by D. H. Lawrence in his impressionistic political novel Kangaroo. ${ }^{36}$ The ex-soldier rioters, along with many right-wing politicians at this time, focussed their propaganda on the drift towards Communist affiliations amongst trade unionists, and sought by implication to brand the ALP as a revolutionary party unsuited for office. Labor politicians soon added their own voice to criticism of tradeunion radicalism, and the Australian Workers' Union withdrew from negotiations to establish the One Big Union. A second All-Australian Trade Union Congress met in Melbourne in June-July 1922, and the formal powers of the One Big Union were strengthened; however, the absence of the Australian Workers' Union and a number of other moderate unions underlined the declining influence of left-wing ideas. ${ }^{37}$

Nevertheless, despite this growing reaction against "Bolshevism" in all its forms the New South Wales Labor Council confirmed its affiliation with the Profintern and in 1922 became the official Australian section of the Red International. At the Labor Council over two thirds of the union delegates at this time had joined the CPA, and at the Fourth Comintern Congress Garden proudly boasted that despite his party's small size it exercised control over more than half of Australia's 700,000 trade unionists. ${ }^{38}$ His claim absurdly exaggerated the real strength of the CPA, or even - for that matter - the Profintern. The Labor Council of New South Wales was quite unable to persuade Trades Halls in other States to estab-

${ }^{36}$ D. H. Lawrence, Kangaroo (London, 1923), written during a brief visit to Australia in May-June 1922.

37 Labor Call, 6 July 1922, p. 4.

38 Fourth Congress of the Communist International: Abridged Report (London, n.d.), p. 230. 
lish contact with the Profintern, and a direct letter of appeal from the Red International to the 1922 All-Australian Trade Union Congress to consider the issue of affiliation was found to have arrived after the congress met. ${ }^{39}$ On the other hand it is quite fair to say that a large proportion of Australia's trade unions did remain open to the influence of radical and left-wing doctrines which the Trades Hall Reds promoted. The continuing importance of left-wing ideology was underlined by the ease with which the Profintern established indirect links with the Australian union movement through participating in the setting up of an entirely new organisation called the Pan-Pacific Trade Union Secretariat or PPTUS, and founded in Hankow, China, in 1927.

\section{III}

\section{THE PAN-PACIFIC TRADE UNION MOVEMENT}

In its world context the PPTUS represented a move by the Profintern to organise the unions of the Far East and Pacific into a regional antiimperialist bloc. ${ }^{40}$ It also represented a significant break-through by the Profintern in establishing itself as a counter-influence to the Europeanbased International Federation of Trade Unions. However, the Secretariat was not able to maintain a permanent presence as a trade-union organisation and lasted only until 1931. Heavily reliant on the KuomintangCommunist coalition in China, it was greatly handicapped by the collapse of that coalition after 1927 and the subsequent repudiation by the Comintern of united-front politics.

In the Australian context the PPTUS found acceptance amongst leftwing unionists as a successor to their own attempts at establishing an international organisation earlier in the 1920's. In fact the Pan-Pacific movement had originated in Australia and was only later taken up by the Profintern. ${ }^{41}$ The All-Australian Trade Union Congress of 1921 carried a resolution to foster solidarity with the labour movements of the Pacific in order to prevent war. However, despite the setting up of a "Council of Action" little progress was made towards implementing the proposal and it met with negative response outside Australia. Eventually the New South

39 Labor Call, 14 September 1922, p. 2.

40 See X. J. Eudin and R. C. North, Soviet Russia and the East, 1920-1927 (Stanford, 1957), pp. 269-70. For interpretative accounts of the PPTUS see J. H. Brimmell, Communism in South East Asia (London, 1959), pp. 65ff.; C. B. McLane, Soviet Strategies in Southeast Asia (Princeton, 1966), pp. 70-71.

41 See F. Farrell, "The Pan-Pacific Trade Union Movement and Australian Labour, 1921-1932", in: Historical Studies (Melbourne), XVII (1977), pp. 441-57. 
Wales Labor Council convened a Pan-Pacific conference in Sydney in 1926. Again there was poor response, but the "preliminary" conference in Sydney opened the way for convening the meeting in Hankow in May 1927. This meeting created the PPTUS to act on a programme broadly in keeping with the anti-war internationalism previously espoused by Australian unionists. ${ }^{42}$ However, the great bulk of the organising work for the conference, and the entire staffing of the PPTUS was the work of the Profintern.

News of Australian attempts to organise a Pan-Pacific conference was conveyed to Moscow by the Garden-led delegation to the CominternProfintern congresses of June-July 1922. Communist sources later urged Red trade unionists to take a leading role in organising such a conference, ${ }^{43}$ and in mid 1924 a poorly attended and hastily convened "Conference of Transport Workers of the Pacific" was held in Canton. The third congress of the Profintern in July 1924 decided that this so-called "bureau" in Canton would serve as a propaganda base and organisational link, "uniting the various countries of the East among themselves on the one hand, and with the R.I.L.U. on the other". ${ }^{44}$ The Profintern congress also decided that the Red International "must form new support bases in the chief ports of the Near and Far East" in the immediate future. ${ }^{45}$ An apparent attempt to establish such a "bureau" in Australia in 1925 proved abortive. ${ }^{46}$

More rapid progress was registered in the growth of Profintern-related trade-union organisations in the Pacific region. Already in May 1924 the Profintern had established contact with trade unionists in the Philippines. ${ }^{47}$ Gains were also made in the setting up of Chinese Nanyang labour organisations in Malaya. ${ }^{48}$ Overshadowing all these developments, however, was the setting up of the All-China Labor Federation in March 1925 and the immediate affiliation of this new national organisation with the Profintern. ${ }^{49}$ In September 1926 the decisions of the preliminary Pacific conference in Sydney were endorsed by the All-China Labor

42 Ibid., esp. p. 447.

${ }^{43}$ See Thèses et Résolutions adoptées au IIème Congrès de l'Internationale syndicale rouge (Paris, n.d.), p. 56; Labour Monthly (London), IV (1923), p. 243.

${ }_{44}$ The Tasks of the International Trade Union Movement, being the Resolutions and Decisions of the Third World Congress of the Red International of Labour Unions (London, n.d.), p. 48. 45 Ibid.

${ }^{46}$ Sydney Morning Herald, 20 and 24 April, 10 July 1928; cf. Inprecorr, 11 September 1924 , p. 705.

${ }^{47}$ See McLane, Soviet Strategies in Southeast Asia, op. cit., pp. 113-31; cf. Inprecorr, 11 September 1924, p. 704.

48 McLane, op. cit., pp. 133, 136.

49 J. Chesneaux, The Chinese Labor Movement 1919-1927 (Stanford, 1968), pp. 259-60.

On the Chinese Labor Federation's role in establishing the PPTUS see Pan-Pacific Worker (Sydney), 2 April 1928, p. 4. 
Federation, and it was under the auspices of this organisation that the Secretariat's first conference was held.

The setting up of the PPTUS demonstrated the Profintern's interest in pursuing united-front policies in the Pacific and Asian region. The Secretariat appealed both to anti-imperialist sentiment in the fledgeling leftwing movements in Asian countries and the vague class-conscious internationalism associated with the Australian unions. That this internationalist sentiment extended well beyond the Trades Hall Reds of New South Wales was underlined by the brief affiliation with the PPTUS of the newly established central co-ordinating body of the union movement, the Australasian Council of Trade Unions.

The ACTU's association with the PPTUS can only be explained by the previous links between Australian unions and the Pan-Pacific movement. By no stretch of the imagination could the early ACTU reasonably be described as Communist or even pro-Communist in outlook, but its affiliated unions were strongly committed to Socialist and anti-war views. They were thus prepared to allow the left-wing New South Wales unions to lead the ACTU towards close co-operation with a like-minded overseas organisation such as the PPTUS professed to be. From 1927 to 1930 (when the affiliation broke down) the ACTU was one of the few majority national union organisations associated with the Secretariat. ${ }^{50}$ Certainly the affiliation represents one of the more startling successes of Profintern policies and bears comparison with the British Trade Union Congress's short-lived involvement with the Anglo-Russian Joint Advisory Council in 1925-26.51

The ACTU was established at an All-Australian Trade Union Congress held in Melbourne in May 1927. The two important developments which had preceded the formation of the ACTU were the setting up of the Commonwealth Industrial Disputes Committee in Adelaide, in 1925, and the holding of the "Third" All-Australian Trade Union Congress in Sydney, in 1926. The formation of the Disputes Committee had served to convince many of the more moderate and craft-based unions that the doctrinaire posturing of the One Big Union advocates had been laid aside, and that co-ordination of the policies and activities of the various Trades Hall Councils was now possible without the rigid subjugation of constituent organisations that the One Big Union idea had entailed. The Third All-Australian Trade Union Congress, on the other hand, was an audac-

50 For Profintern discussion of the ACTU's affiliation with the PPTUS see L'Internationale syndicale rouge au travail, 1924-1928 (Paris, 1928), esp. pp. 180-83.

51 For a comprehensive study of the Anglo-Russian Joint Advisory Council see Calhoun, The United Front, op. cit. 
ious attempt by the trade unions to force the Labor Party to oppose a proposal by the conservative Bruce-Page Government to extend the Commonwealth's powers, a proposal which unionists feared could lead to the undermining of wages and conditions throughout Australia. ${ }^{52}$ Called by A. C. Willis, on his authority as secretary of the Council of Action, the 1926 congress served to convince many unionists of the necessity to agree upon a form of machinery through which they could press their claims upon the Labor Party and co-ordinate their resistance to the anti-union policies of the Bruce-Page Government. ${ }^{53}$ The Third All-Australian Congress had tended to be dominated by the New South Wales unions, with relatively few delegates in attendance from other States; the 1927 Congress attracted representatives from almost all unions except the Australian Workers' Union and organisations under its influence. The founding congress of the ACTU was certainly more widely attended than any since the Union Congress of $1921 .{ }^{54}$

The proceedings of the 1927 congress closely reflected the forces at work in the union movement over the previous few years. This congress was more moderate in its debates and resolutions than earlier congresses. At the same time the congress declared that the aim of the union movement remained "the socialisation of production, distribution and exchange", and continuing interest in internationalism was underlined by a motion urging the establishment of a Peace Bureau. ${ }^{55}$ Shortly after this the ACTU executive announced its affiliation with the PPTUS, a decision endorsed by a full trade-union congress in 1928.

A meeting of the PPTUS was held in Shanghai in February 1928, chaired by the Australian representative J. Ryan (director of the ACTU-affiliated Labour Research and Information Bureau). Ryan was at this time a Communist, though he was better known for propaganda work on behalf of trade unions associated with the Sydney Trades Hall. Later in 1928 Ryan represented the PPTUS at the Ninth All-India Trade Union Congress held in Jharia. ${ }^{56}$ At the Shanghai meeting the ACTU's offer to hold the second

52 On the Third All-Australian Trade Union Congress's effect on the ALP's political stance see A. Wildavsky and D. Carboch, Studies in Australian Politics (Melbourne, 1958), pp. 80ff.

${ }^{53}$ Official Report of the All-Australian Trade Union Congress (Melbourne, 1927), pp. 1, $8,10$.

54 The All-Australian Trade Union Congress of 1921 claimed to represent all of Australia's 700,000 trade unionists. The ACTU claimed to represent approximately 500,000 unionists. For an estimate of the ACTU's real strength at this period see J. Hagan, The ACTU: A Short History (Sydney, 1977), esp. pp. $31 \mathrm{ff}$.

55 Official Report of the All-Australian Trade Union Congress, op. cit., pp. 19-20.

56 Pan-Pacific Worker, 1 April 1929, p. 8. 
Pan-Pacific conference in Australia was accepted, and it was also decided to publish the Secretariat's journal, the Pan-Pacific Worker, in Australia. ${ }^{57}$

The body with which the ACTU had affiliated was a rather strange collection of unions and propagandist organisations. ${ }^{58}$ The largest affiliate was the All-Russian Council of Trade Unions (10,000,000 members), while many other affiliates represented left-wing fringes of national trade-union bodies, such as the British National Minority Movement and the American Trade Union Educational League, or breakaway minorities, such as the French Confédération Générale du Travail Unitaire. Of the Secretariat's affiliates in the Asian and Pacific region the largest were the All-China Labor Federation, with 2,800,000 members, and the ACTU, with 500,000. Left-wing and Anarchist unions in Japan and the fledgeling labour movements of the Philippines, Indonesia and Korea made up the remainder of the Secretariat's membership.

The weaknesses which frustrated earlier Australian attempts to promote a Pan-Pacific movement thus remained. Given the low stage of development of trade-union organisations in the region it was not possible to forge more than token links between them. Furthermore the unifying left-wing ideology of the Red International also ensured that more nationalist and conservative union groupings in Japan and the United States now viewed the Pan-Pacific idea with suspicion and repugnance. So despite its apparently large total membership the PPTUS remained extremely weak.

The Secretariat's appeal narrowed still further as the Comintern entered its so-called third period. At its Sixth Congress in July-August 1928 the Comintern declared that the period of post-war capitalist development, when the Communist movement had been able to coexist with the West, was now giving way to an economic crisis which would lead to increased danger of war against the Soviet Union. ${ }^{59}$ The Congress announced that a return to the Leninism of the immediate pre-war years was called for and that Communists must take the lead in opposing the capitalist class. All other Socialist and reformist groups and parties ("social fascists" in the new terminology) henceforth were to be regarded as supporters of the bourgeoisie.

The world Communist movement's swing to the left had begun before the Sixth Comintern Congress. The fourth Profintern congress of May 1928

57 Ibid., 15 April 1928, p. 1; G. Hardy, Those Stormy Years (London, 1956), p. 198.

58 For slightly varying estimates of the numerical strength of the PPTUS see A. Lozovsky, The Pan-Pacific Trade Union Conference (Moscow, 1927), pp. 13-14; L'Internationale syndicale rouge au travail, op. cit., p. 106.

59 For accounts of third-period policies see World Communism, pp. 84-85; McLane, Soviet Strategies in Southeast Asia, pp. 64-70. 
discussed the "capitalist offensive" in a rather general way, but noted that the "leftward drift of the masses [...] is a zig-zag, devious process", ${ }^{60}$ and left considerable room for manoeuvre. Over the next few years the old united-front policy of the Profintern was to coexist uneasily with the new line. In Germany, the USA, France and Britain the implications of the new line for trade-union activity were soon drawn out in the course of power struggles closely involved in the tightening control exercised by Stalin over the international Communist movement. In Australia, by contrast, the state of confusion was allowed to continue until the beginning of 1931.

The anomalous situation in Australia may have been in part due to the involvement of the ACTU with the PPTUS. The Sixth Comintern Congress had made an exception of colonial and semi-colonial countries, where the task of Communist parties was to support bourgeois-democratic revolution in preparation for the second step of proletarian dictatorship. This was, of course, an extremely difficult policy to apply given the links between the left-wing and Communist movements of capitalist countries and the colonial world. By about 1930 Moscow had come to treat revolutionary prospects in the East as parallel to those elsewhere in the world.

Certainly, the PPTUS was from this time on set on a road to oblivion. By 1930 the Kuomintang had so weakened the All-China Labor Federation that it was almost moribund. The Secretariat itself existed as a small clandestine organisation in Shanghai, finally suppressed by the arrest of its key operatives in June $1931 . .^{61}$ In India the early interest of the union movement had faded in the face of intense criticism of the trade-union leadership by the PPTUS. ${ }^{62}$ In the Philippines a split developed in the unions which composed the Secretariat-affiliated Congreso Obrero de Filipinas. A pro-Communist faction seceded, in early 1930 establishing a new "Proletarian Labor Congress" and in November of that year formally inaugurating a Philippines Communist Party. ${ }^{63}$

The second Pan-Pacific conference was held in August 1929 in Vladivostok, after ACTU attempts to have the conference held in Australia had foundered on the resolute opposition of the Bruce-Page Federal

60 Report of the Fourth Congress of the R.I.L.U. (London, 1928), p. 13.

61 C. A. Willoughby, Shanghai Conspiracy (New York, 1952), esp. pp. 283-90, 302-08.

62 See Pan-Pacific Monthly (San Francisco), May 1929, pp. 33-36; February 1930, pp. 15-22. The 1929 All-India Trade Union Congress at Nagpur split over the question of Secretariat affiliation and other issues related to the programme championed by a powerful and vocal Communist delegation. Subsequently the PPTUS retained only one firm Indian affiliate, the Girni Kamgar (Textile Workers') Union.

63 Pan-Pacific Worker, 1 October 1930, pp. 316-17; Brimmell, Communism in South East Asia, op. cit., pp. 103ff.; McLane, Soviet Strategies in Southeast Asia, pp. $165 \mathrm{ff}$. 
Government. Many delegations failed to reach Vladivostok on time and a second gathering of PPTUS representatives was convened in Shanghai. ${ }^{64}$ The Vladivostok meeting discussed the drift to open conflagration in the Pacific and issued a number of resolutions couched in a curious mixture of third-period jargon and united-front overtures, calling for transformation of the class struggle into war against imperialism. ${ }^{65}$ Already, however, very few labour organisations outside the Communist movement were listening.

The ACTU's break with the Secretariat came in early 1930. The ACTU delegation had arrived in Vladivostok too late to participate in the PanPacific conference, but immediately entered into a plenary session of the Secretariat where the Australian question was discussed. In the course of the plenary session, and in subsequent discussions between delegates from the Labor Council of New South Wales and the Profintern, the PPTUS's swing to the left was made clear. ${ }^{66}$

The Secretariat's differences with the ACTU focussed on the attitude of the Australian unions towards industrial arbitration and the White Australia policy. The PPTUS insisted that both these institutions should be repudiated, an attitude which Australian unions regarded as unnecessary interference in the ACTU's affairs. Repudiation of the arbitration system would have resulted in a massive lowering of wage levels, whilst a campaign against the White Australia policy was thought of as impractical given the current concern of Australians with the very high level of unemployment. ${ }^{67}$ Angered by the Secretariat's recommendations on these questions the ACTU congress of February 1930 rejected a motion to continue affiliation with the PPTUS. ${ }^{68}$

The dispute between the ACTU and the Pan-Pacific Secretariat brought an end to the interest of most unions in internationalism. Born of anti-war Socialism and sustained by idealism and naivety, the affiliation with the PPTUS had demonstrated the ACTU's willingness to oppose war and assist the victims of imperialism. Attempts to turn the PPTUS into an instrument for directing affiliated union movements towards adopting Communist policies produced an emotional reaction against such extremism. Throughout the early 1930's the ACTU adopted a policy of isolationism and lack of concern with events outside Australia.

${ }_{64}$ Pan-Pacific Worker, I November 1929, pp. 6-11.

65 See ibid., 2 December, esp. pp. 10-20; A. Lozovskij, Protiv vojny, imperializma i reformizma: Doklad i zaključitel'noe slovo na Tichookeanskoj konferencii profsojuzov 16 avgusta $1929 \mathrm{~g}$. (Moscow, 1929).

66 Pan-Pacific Worker, 2 December 1929, pp. 20-22; I March 1930, pp. 65-75.

67 ACTU debate of these matters is reported in the Australian Worker, 28 February 1930.

68 Ibid., 5 March. 
THE MILITANT MINORITY MOVEMENT

The break between the ACTU and the PPTUS was accompanied by an outburst of bitter and sectarian politics in the labour movement. In early 1930 a new outspokenly third-period leadership assumed power in the CPA. ${ }^{69}$ The CPA now attacked not only the "trade-union bureaucrats" in control of the ACTU, but paid particular attention to the "left socialfascist" leadership of the New South Wales Labor Council. In place of the united front of the 1920's the CPA now aimed at a "united front from below", which meant toppling the Trades Hall Reds and other Socialists from leadership of the left-wing unions and replacing them with members of the Communist Party. The main vehicle of the Communist attack on the labour Left was a previously little-known organisation called the Militant Minority Movement.

The MMM had been formed in 1928 out of several small propagandist bodies associated with the CPA. ${ }^{70}$ Its supporters included a number of ex-members of the IWW who had broken away from the Communist Party in 1922 in opposition to the united front, but who had retained some links with the Profintern. ${ }^{71}$ In the strike-prone atmosphere which preceded the Great Depression in Australia the MMM made some gains in membership and influence. However, it was seriously restricted in the Sydney region by the New South Wales Labor Council, which as an official Profintern affiliate was responsible for co-ordinating left-wing trade-union activities. The Council's affiliation with the Profintern was now seen as a considerable hindrance to the power of the CPA, and the party's new-line leadership sought to expand MMM activities in the trade unions and at the same time discredit the standing of Garden and the Trades Hall Reds in the eyes of the Profintern.

Despite the world Communist movement's swing to the left, the Profintern did not direct serious criticism towards the Labor Council before the early 1930's. Indeed, in the late 1920's the links between the Trades Hall Reds and the Profintern had improved somewhat, due principally to the development of the Pan-Pacific trade-union movement. At the fourth congress of the Red International Garden had been elected to the Profintern executive. ${ }^{72}$ There was, however, little real understanding of the Labor Council's affairs and following the plenum discussion on Australian

69 See Workers' Weekly, 3 January 1930 , p. 1.

70 Davidson, The CPA, p. 37.

71 Communist, 10 February 1922, p. 1; Direct Action, March 1922, p. 1.

72 See Lazitch and Drachkovitch, Biographical Dictionary of the Comintern, p. 115. 
trade unions in Vladivostok in late 1929 the Profintern addressed a letter to the Council criticising its relatively decentralised control over affiliated unions and equivocal attitudes on the question of arbitration. Coming at the same time as CPA and MMM attacks on "social fascism", the Profintern's letter provoked considerable anger when it was considered by the Labor Council. ${ }^{73}$ Subsequently unions affiliated with the Council were not prepared to finance an official delegation to the fifth RILU congress in Moscow, and the field was left open to an MMM delegation led by L. L. Sharkey, one of the new leaders of the Communist Party.

Still, despite the rupture in relations between the Profintern and the Labor Council the situation was not finally clarified for almost another year. Throughout this period Garden continued occasionally to claim that the Labor Council remained affiliated with the RILU and that the CPA was wrongly interpreting the policy of the world Communist movement. ${ }^{74}$ In reality, however, the vestiges of revolutionary radicalism were rapidly fading from a union leadership swamped by the unemployment problem and the massive strike defeats which had heralded the onset of the depression in Australia. The Trades Hall Reds, like almost all left-wing union leaders, increasingly sought an accommodation with elected State and Federal Labor Governments to compensate for their extreme industrial weakness. In particular the radical demagogy of the second Lang Government (1930-32) in New South Wales owed much to the support given it by the Labor Council. ${ }^{75}$

The Profintern finally publicly repudiated the Labor Council in January 1931, charging the Garden-led radicals with "dragging the Council [into] the orbit of the social fascists". ${ }^{76}$ The Profintern announced its full support of the MMM and the "RILU Vigilance Committees", which were attempting to remove the left-wing union leaders from the Labor Council and its affiliated unions. ${ }^{77}$ Lozovsky also issued a statement condemning Garden for his "anti-working class activity" and opposition to the MMM. ${ }^{78}$ Henceforth the Profintern's influence was restricted to the CPA-controlled Minority Movement.

So by 1931 the MMM was firmly established as the Australian section of the RILU, though its membership and influence remained very small indeed. With unemployment moving towards $28 \%$ of the workforce by

73 Labor Daily, 21 March and 2 May 1930.

74 Ibid., 26 September.

75 Jack Lang, op. cit., esp. chs 3 and 4.

76 Pan-Pacific Worker, 5 January 1931, p. 10.

77 Ibid.

78 Workers' Weekly, 31 July 1931, p. 2. 
early 1932 there was little room for the application of militant strike tactics, and MMM-inspired industrial activity recorded few successes. The MMM's rigid adherence to the fifth Profintern congress's policy of an industrial offensive and general strike ensured that the organisation had little appeal to the wider workforce. ${ }^{79}$ Nor did those in employment show any interest in the one or two confused and resoundingly unsuccessful attempts at dual unionism which were conducted by the CPA in parallel with MMM activities in the established trade unions. ${ }^{80}$ There was, however, a feeling of bitter resentment and frustration on the part of many militant rank-and-file unionists and the MMM was able to cater to this need. In August 1931 the MMM began regular publication of its own propaganda organ, the Red Leader, which quickly attained a circulation in excess of 10,000. Membership of the MMM, however, remained under 1,000 in 1931 and was still slightly under 3,000 in early $1933 .{ }^{81}$ On average about half the membership were also members of the CPA, and executive positions on the "National Committee" of the MMM remained fairly firmly under the control of the party.

Nevertheless the MMM was able to exert a growing influence on rankand-file union attitudes as the economic situation began to improve. In 1933 and 1934 MMM candidates began to win positions of significant power in the trade-union movement. The first major victory was in the Miners' Federation, which elected an MMM nominee as Federal secretary in $1934 .^{82}$ The MMM had also established itself as a national organisation, and extended well beyond its original bases in State branches of unions such as the carpenters and joiners' and tramways' unions. By 1935 the Minority Movement was prepared to claim decisive influence in a number of major unions including the Miners' Federation, the Australian Railways' Union and the Federated Ironworkers' Association. ${ }^{83}$

Already by this time, however, the MMM was working again with the "left social fascists". The CPA's efforts to unseat the old left-wing leadership in the unions had met with some stiff resistance. Though there were individual successes in unions such as the Miners' Federation, in many

${ }^{79}$ See Tasks of the Red Trade Unions and MMM: Resolutions of the Fifth Congress RILU (Sydney, 1931).

80 The experiments in dual unionism in which the CPA and the MMM became involved were the Pastoral Workers' Industrial Union of Australia (formed by AWU militants in 1930 and disbanded by the CPA in 1936) and an unsuccessful attempt in 1932 to establish a section of the Hamburg-based International of Seamen and Harbour Workers.

81 Red Leader, 4 January 1933, p. 2.

82 Ibid., 3 January, p. 1.

83 Ibid., 17 July 1935, p. 3; Davidson, The CPA, p. 60. 
other cases the results had been negative or had led to a stalemate. The left-wing leadership of the Australian Railways' Union affiliated with the Profintern in 1931, but continued to pursue independent policies and fought continuously with the RILU Vigilance Committees controlled by the $\mathrm{MMM}^{84}$ When $\mathrm{MMM}$-controlled unions sought to influence the wider labour movement, their initiatives often met with vigorous rebuff. It was thus soon realised that the continued extension of MMM influence depended on an accommodation with the non-Communist Left, and when the Comintern and Profintern began to soften their adherence to thirdperiod policies after 1933 the MMM quickly followed suit.

The adoption of a new "popular front" policy on the part of the Communist movement was a reaction to the spread of Fascism in Europe. It came slowly at first and was applied haltingly until formalised by the Seventh Congress of the Comintern in July-August 1935. In effect it was the old united-front policy of the 1920's applied increasingly loosely to any groups in the community which could conceivably be described as "antifascist". For the Profintern this policy was manifested in the revival of interest in schemes of reconciliation with the International Federation of Trade Unions, such as that proposed in early $1935 ; 85$ in progressive closing down of its national sections in favour of unity with anti-fascist forces in the world trade-union movement, and finally in the complete liquidation of the Profintern in 1937. ${ }^{86}$

In Australia the turning point came with the visit of the Czech antifascist journalist and writer Egon Kisch late in $1934{ }^{87} \mathrm{His}$ clash with immigration authorities (who tried to prevent him from entering the country to address anti-war and anti-fascist rallies) sparked a powerful protest movement across the Left of the political spectrum and laid the foundation for the growth of a popular front. For the MMM it provided an opportunity to co-operate with a spectrum of left-wing unionists on a political issue which could unite Communists, Socialists and civil libertarians. ${ }^{88}$ In order to facilitate the growing united front the MMM was disbanded. In July 1935 the last issue of Red Leader appeared. ${ }^{89}$

84 Red Leader, 11 January 1933, p. 4. On the ARU's affiliation with the Profintern see ibid., 14 September 1932, p. 14; 26 September 1934, p. 4; F. Nolan, You Pass This Way Only Once (Brisbane, 1975), ch. 5.

85 See Red Leader, 3 April 1935, p. 2.

86 World Communism, p. 376.

${ }^{87}$ See E. Kisch, Australian Landfall (London, 1937; Sydney, 1968).

88 See Red Leader, esp. 2 January 1935, p. 2; 27 February, p. 2.

89 Ibid., 17 July, p. 3. Subsequently some attempt was made to continue the co-ordination of union opinion achieved by Red Leader through publication of the Trade Union Leader, a monthly journal of left-wing commentary. 


\section{CONCLUSION}

What is clear from this account of the Profintern's relations with the labour movement is the importance of united-front strategy in the extension of Communist influence in the trade unions. The Profintern's united-front policy allowed it (even if only briefly) to establish indirect links at the highest level of trade unionism, while the crucial role played by the Trades Hall Reds throughout the 1920's was only possible while the RILU maintained a loose and undemanding attitude towards its affiliates. Thus the impact of the Russian Revolution in Australia was greatly magnified in the trade unions in an era when Communism had not yet acquired the connotations of totalitarianism and subjection to Russian national interests that were later so obvious.

From the point of view of Communist theory, of course, the situation in Australia in the 1920's was most unsatisfactory indeed. The Trades Hall Reds were unorthodox pragmatists, always capable of bending principles to the achievement of immediate and practical goals. More broadly, the Australian unions were committed to vague and contradictory notions of Socialism which were essentially compromise in nature. In particular the "national" and reformist influence of the ALP remained very strong, and the union movement's enthusiasm for anti-war internationalism did not provide a sufficient basis for the lasting development of a revolutionary ideology. In this respect, at least, the adoption of third-period policies allowed a "purification" of Communism.

Even so the realisation by the CPA in the 1930's that it was only possible to extend its influence in the trade unions by united-front tactics underlined the effectiveness of the Profintern in earlier years. The experience of the MMM had shown that in a complex and well-established labour movement such as existed in Australia it was impossible for any minority ideological organisation to exert more than a refractory influence on the overall course of activity and opinion. This the earlier relationships between Australian unions and the Profintern had already clearly demonstrated: left-wing trade unionists could never be "controlled" by a party as small as the CPA. 